This item was submitted to Loughborough's Research Repository by the author.

Items in Figshare are protected by copyright, with all rights reserved, unless otherwise indicated.

\title{
Exploring the impact of customer feedback on the well-being of service entities - a TSR perspective
}

\section{PLEASE CITE THE PUBLISHED VERSION}

http://dx.doi.org/10.1108/JOSM-01-2014-0022

\section{PUBLISHER}

(c) Emerald Group Publishing Ltd.

\section{VERSION}

AM (Accepted Manuscript)

\section{PUBLISHER STATEMENT}

This work is made available according to the conditions of the Creative Commons Attribution-NonCommercialNoDerivatives 4.0 International (CC BY-NC-ND 4.0) licence. Full details of this licence are available at: https://creativecommons.org/licenses/by-nc-nd/4.0/

\section{LICENCE}

CC BY-NC-ND 4.0

\section{REPOSITORY RECORD}

Nasr, Linda, Jamie Burton, Thorsten Gruber, and Jan Kitshoff. 2019. "Exploring the Impact of Customer Feedback on the Well-being of Service Entities - a TSR Perspective". figshare. https://hdl.handle.net/2134/15830. 
Exploring the impact of customer feedback on the well-being of service entities: A TSR perspective Published in Journal of Service Management, 2014, Vol. 25 No. 4, pp. 531-555

Linda Nasr

Manchester Business School

University of Manchester

Manchester

UK

Jamie Burton

Manchester Business School

University of Manchester

Manchester

UK

Thorsten Gruber

School of Business and Economics

Loughborough University

Loughborough

UK

Jan Kitshoff

KitshoffGleaves \& Co

Warrington

UK 


\section{Exploring the impact of customer feedback on the well-being of service entities: A TSR perspective}

\section{Introduction}

Marketing in general and services in particular have been blamed for damaging, disregarding, and maltreating consumer's well-being in a multitude of ways; either by having a patronizing style of service delivery, or by underserving groups in needs (Fisk, 2009). As a result, the Transformative Service Research (TSR) movement began. Emerging at the intersection of transformative consumer research and service research (Anderson et al., 2013), TSR is defined as "service research that centers on creating uplifting changes and improvements in the well-being of individuals (consumers and employees), families, social networks, communities, cities, nations, collectives, and ecosystems" (Ostrom et al., 2010, p. 6). Due to the direct and dialogic interaction between the service company and the customer, this dynamic nature of services presents substantial transformative potential (Anderson et al., 2010). Anderson et al. (2013) present a framework illustrating how interaction between service entities and consumer entities influences the wellbeing of both. Service entities include employees, processes, offerings, organizations, and service sectors, while consumer entities comprise individuals, collectives, and the ecosystem (Anderson et al., 2013). Therefore, when any consumer entity interacts with any service entity, during a value-creation process, potential well-being outcomes are generated for both parties such as access, health, life satisfaction, harmony, power, respect, support, and happiness (Anderson et al., 2013).

In light of the above, we propose that customer feedback generated during a value creation process, can have potential well-being outcomes on service and consumer entities. According to Lusch and Vargo (2006), "conversation and dialogue" (p. 413) is one of the four building blocks of a company's strategic marketing direction. Customer feedback, a particular type of "conversation and dialogue", allows companies to listen to customers to understand what it is that they value in the company (Vargo and Lusch, 2008). Previous research has proposed various important outcomes of customer feedback management, such as: assistance in performance assessment, facilitation of organizational learning (Babbar and Koufteros, 2008), improvement of overall service quality (Wirtz et al., 2010), better decision making (Bitner et al., 1994) and generation of competitive advantage (Lusch et al., 2007). However, the impact of customer feedback on the service entities' well-being remains an overlooked area.

Adopting a TSR approach, this study aims to address this gap by exploring the impact of customer feedback on the well-being of service entities. Moreover, inspired by the objectives of TSR to "create uplifting changes and improvements in the well-being" (Ostrom et al., 2010, p. 6), the importance of positive customer feedback is stressed. Positive customer feedback is a highly under-researched topic. Most previous research has approached customer feedback from a negative lens, focusing on the impact of 
customer complaints, dysfunctional customer behavior and service recovery, on front-line employees and companies in general. Accordingly, this paper focuses on exploring the impact of positive customer feedback on the well-being of front-line employees and its outcome for companies, since front-line employees are the main recipients of customer feedback (Lovelock and Wirtz, 2010). Moreover, working within the TSR framework, employees' and managers' perceptions about the impact of positive feedback on society are proposed. Finally, a comparison of employees' and managers' perceptions about positive feedback is presented.

The remainder of the paper is organized as follows: given the current lack of knowledge concerning positive customer feedback impact and associated well-being outcomes, an extensive multidisciplinary literature review was conducted, followed by two exploratory qualitative research studies with managers and front-line employees in service companies. This resulted in the development of the "Positive Feedback Model" (PFM) contributing to the growing TSR movement. Subsequently, a comparison of managerial and employee views around positive customer feedback is presented. The paper concludes with a summary of the main contributions and limitations of the study, and presents directions for future research.

\section{Literature review}

\section{Customer feedback}

Customer feedback is defined as customer communication concerning a product or a service (Erickson and Eckrich, 2001). Customer feedback can be either solicited or unsolicited (Berry and Parasuraman, 1997). Solicited feedback is encouraged by the company through the usage of tools such as surveys and focus groups that invite customers to give feedback (Sampson, 1996). In contrast, unsolicited customer feedback relies on the customer's own desire and will to communicate his/her experiences (Sampson, 1996). Taking this categorization a step forward, Day and Landon (1977) distinguish between two types of unsolicited customer feedback: private and public communication. They define private communication as interpersonal communication while public communication is that addressed to the firm. Interpersonal communication of unsolicited customer feedback is manifested through Word of Mouth (WOM). Moreover, other types of interpersonal feedback have been introduced due to the rise of internet usage. In a recent article, Blazevic et al. (2013) introduced the concept of customer-driven influence (CDI) defined as "the impact of customers' verbal and non-verbal communication on other customers' attitudes and behaviors" (p. 295). With the rise of social media, CDI is taken to a new level of connectedness where networking sites, video sharing, recommendation blogs, and wikis have changed how customers interact with each other, which has accordingly led to changes in relationships between customers and companies (Libai et al., 2010). 
Computer-mediated communication led to the rise of the electronic word of mouth (eWOM) (Litvin et al., 2008). Thus, social media presented a new channel of feedback, where once privately communicated feedback is now public. Finally, customer influence is no more restricted to verbal WOM communication, as a new conceptualization includes non-verbal communication (Libai et al., 2010). This became more apparent with the rise of social media usage, where it is possible to non-verbally express attitudes about particular companies, for example by liking a particular company on Facebook or following a particular brand on Twitter (Blazevic et al., 2013).

Adopting the TSR approach, the focus of this study is on the unsolicited public feedback addressed to front-line employees since they are the main recipients of customer feedback (Lovelock and Wirtz, 2010).

\section{Feedback valence}

Customer engagement is a growing research stream within customer management research (Verhoef et al., 2010). Acknowledged as a form of customer engagement, customer feedback can be of positive or negative valence or it can also be valence-free taking the form of suggestions and comments (Doorn et al., 2010). We contend that 5 types of customer feedback ( $5 \mathrm{Cs}$ ) can be identified: (i) positive Compliments; (ii) negative Complaints; (iii) valence free Comments (e.g., a customer outlining how they use a product); (iv) Concerns (when the customer outlines an issue that is not a complaint, but has the potential to become a problem if not addressed) and (v) Counsel (suggestions and constructive critical reviews). In the area of service research, there have been various calls to study the negative outcomes of service such as service failures and customer dissatisfaction (Schneider and Bowen, 1999). This is due to the prevalence of failures during service encounters (Maxham and Netemeyer, 2002). Therefore, it has been proposed that organizations should engage in "dissatisfaction management" and service recovery in order to improve service quality (Kasper et al., 1999). Consequently, in the customer feedback area, customer complaining behavior has been thoroughly researched. It was pioneered by Best and Andreasen (1977) and thereafter has been the focus of many scholars, leaving complimenting behavior marginalized. Moreover, complaint management has been pioneered in theory and practice as it is proved to ensure high levels of customer satisfaction and loyalty (Smith et al., 1999) and increased market share (Fornell and Wernerfelt, 1987). Additionally, neuroimaging evidence shows that negative emotions enhance memory accuracy, therefore the focus on complaints can be explained by evidence that people tend to memorize the negative more vividly than the positive (Kensinger, 2007). By adopting a TSR approach, this study focuses on the largely under-researched field of positive valence of feedback. We adhere to Kraft and Martin's (2001) categorization where positive feedback is defined as a compliment taking the form of an acknowledgment or an expression of gratitude. 
In the business literature, there is no concrete and unified definition for the word "compliment" as for other common business terms such as quality, performance, contribution and development. The reason for this lack of definition is explained by Kraft and Martin (2001) as due to the subjective nature of the term "compliment". Compliments are primarily researched in linguistics and sociolinguistics studies. Hatch (1992) defines compliments as 'expressives'; indicating the degree to which someone or something is liked. Herbert and Straight (1989) refer to compliments as: "expressions of personal praise" (p. 37) while Holmes (1986) defines a compliment as: "A speech act which explicitly or implicitly attributes credits to someone other than the speaker, usually the person addressed, for some 'good' (possession, characteristics, skill, etc.) which is positively valued by the speaker and the hearer" (p. 485). In sum, the various definitions presented in the linguistic and sociolinguistics literature unite around the function of compliments to "oil the social wheels, to increase or consolidate solidarity between people" (Holmes, 1986, p. 499).

Various classifications have been presented for compliments. Manes and Wolfson (1981) identified three topics of classification for compliments: The first topic is appearance and possessions; the compliment in this case is about a particular aspect of physical appearance or physical belongings. The second topic is performance, skills and abilities, such as education and promotion. Finally, the third topic is personality traits. Another classification was presented by Kraft and Martin (2001) based on the object or the recipient of the compliment; a compliment can be directed towards a company, a particular manager of a department, a product or service brand, front-line personnel, other customers present during the service exchange, or even the customer him/herself.

Gratitude related research has been substantially neglected by the field of psychology as researchers displayed a preference for studying human vice rather than virtue (Myers and Diener, 1995). However, research on gratitude has developed recently due to the growing field of positive psychology (Young and Hutchinson, 2012). Positive psychology rediscovered gratitude as a positive emotion (Fredrickson, 2004) that contributes to social and emotional well-being (Howells and Cumming, 2012). The notion of exchange between two parties, referred to as beneficiary and benefactor is essential for gratitude (White, 1999) to take place.

According to Young and Hutchinson (2012), gratitude has both short and long term effects on individuals. More specifically, gratitude has been found to enhance favorable life appraisal and optimism (Emmons and McCullough, 2003), foster social support and protect against stress and depression (Wood et al., 2008), predict social integration, pro-social behavior, and life satisfaction (Froh et al., 2010), and increase relationship satisfaction while being a "booster shot" for the relationship (Algoe et al., 2010, p. 217). 
The literature reviewed reveals a lack of research on positive customer feedback in the services area; therefore, we aim to address this gap by exploring in depth the occurrence of unsolicited public positive customer feedback, in the form of compliments and expression of gratitude, and its potential outcomes.

\section{Importance of front-line employees}

The majority of unsolicited feedback is addressed in-person to front-line employees (Lovelock and Wirtz, 2010); therefore the focus in the study is on the unsolicited public positive feedback addressed to these employees. Front-line ("boundary spanning”) employees, play a crucial role in a service organization. A boundary spanning employee includes any organizational employee who "engages in job-related interactions with a person who is considered part of the environment, who is not a member of the organization" (Robertson, 1995, p. 75). Thus, a front-line employee is a customer-contact employee such as a customer service representative, service technician, retail employee, delivery person, nurse, or professional buyer who works under the limitations of both the internal organizational environment and the external environment (Edmondson and Boyer, 2013).

Previous research shows that for customers, the most direct proof of service happens during the service encounter or "moment of truth"; when they interact with front-line employees (Bitner et al., 1994). Hartline et al. (2000) state that front-line employees are in many cases "the first and only representation of the service firm" (p. 35). Thus, the human interaction component within a service is essential in the service evaluation as it is the behavior and attitude of front-line service employees that primarily affect customers' perception of service quality (Hartline and Ferrell, 1996).

For the company, front-line employees are the main source of information about the customers and the process of resource integration in the service encounter (Bettencourt et al., 2001). Information gathered by front-line employees is beneficial in two ways: firstly, this knowledge can be used by contact employees to improve the interactions with potential future customers; secondly, this knowledge can be used by the company for better decision making (Bitner et al., 1994). Consequently, van der Heijden et al. (2013) found that multiple person-to-person interactions provide front-line service staff with chances to capture customer responses, improve organizational processes, and conduct service recovery.

Rayport and Jaworski (2004) consider that front-line employees' "interactions with customers ... are, for many businesses, the sole remaining frontier of competitive advantage" (p. 48). Realizing the importance of the relationship between customer service evaluation and front-line employees' behavior and attitude during a service encounter, many scholars stress the need for better human resource management for service quality (Bateson, 1995; Bowen et al., 2000). 
Considered an area of interest within positive psychology, well-being research is encouraged across a range of disciplines such as healthcare and education, which are large service industries with explicit transformative mission and intent, and organizational behavior. Luthans (2002) introduced Positive Organizational Behavior (POB) theory as "the study and application of positively oriented human resource strengths and psychological capacities that can be measured, developed, and effectively managed for performance improvement in today's workplace" (p. 59). The main assumption behind the creation of POB is based on the idea that in today's economy, governed by global competition, unlimited access to information, technological advancement, and rising barriers of entry, success cannot be achieved by simply trying to fix what is wrong (Luthans and Youssef, 2007). Accordingly, a number of researchers in the organizational behavior field, inspired by positive psychology, called for a more positive approach to organizational behavior theory (Quick and Quick, 2004; Money et al., 2009).

Previous research has examined the impact of negative customer feedback on front-line employees (Bell and Luddington, 2006). Inspired by the POB theory that fits the chosen TSR approach, we opted to explore the impact of positive customer feedback on the Psychological Capital (PsyCap) of front-line service employees. PsyCap comprises the positive and developmental state of a person (Luthans and Youssef, 2004). It consists of state-like factors establishing the foundation of POB theory (Luthans, 2002; Luthans and Youssef, 2004). The state-like components of PsyCap are: Hope, Self-Efficacy, Resiliency, and Optimism; forming the acronym HERO (Figure 1).

Insert Figure 1 about here

HERO meets the inclusion criteria of PsyCap since it is based on theory and valid measures, consists of state-like rather than trait-like components that are open to development and training, in addition to having an impact on performance (Luthans and Avolio, 2009). PsyCap has been found to be related to various attitudinal, behavioral, and performance outcomes (Avey et al., 2010).

PsyCap is selected for this study based on the findings confirming that PsyCap capabilities have a positive impact on employees' psychological well-being (Avey et al., 2010). Psychological well-being in the workplace is the emotional and purposive psychological state that people go through at work (Robertson and Cooper, 2011). It has two important features: (a) the hedonic well-being or the emotional state (also known as the feeling of happiness) experienced at work and (b) eudaimonic well-being or the degree to which people recognize that their work has a purpose (Robertson and Cooper, 2011). 
Robertson and Cooper (2011) found that improved employee psychological well-being has positive individual outcomes such as: increased productivity and job satisfaction, enhanced morale and motivation, and reinforced employee engagement and commitment. Spector's (1997) review suggests that employee's well-being links with job performance and job satisfaction. He proposes that satisfied employees are more punctual, cooperative, helpful and time efficient. Harter et al. (2002) confirmed that the well-being of employees and their job satisfaction levels affect their sense of citizenship at work, turnover rates, and performance ratings. This in turn will create positive organizational outcomes such as customer satisfaction (Robertson and Cooper, 2011). Harter et al. (2002) found that improved employee well-being not only increases customer satisfaction but also reinforces and strengthens customer loyalty. By being punctual, efficient and cooperative, employees are positively affecting the satisfaction and loyalty levels of their customers during service encounters. High levels of psychological well-being amongst employees form a win-win situation for employees and customers and could have a trickle-down effect on organizations and communities (Harter et al., 2002). The TSR framework is also constructed around these two key types of well-being, where both eudaimonic and hedonic well-being can be appropriately applied to individuals, collectives, and ecosystem levels (Anderson et al., 2013). Consequently, it is proposed that the various categories of positive customer feedback will have an impact on the PsyCap of front-line employees which will affect their well-being. Accordingly, various attitudinal, behavioral, and performance related outcomes will be generated.

Based on the literature reviewed, no prior studies have explored positive customer feedback in the services area. Therefore, an exploratory study was deemed necessary for the following reasons: First, the projection of the extensive knowledge around negative feedback categories and impacts is not suitable in the positive feedback context. Second, in order to develop a model of components and outcomes of positive feedback ("Positive Feedback Model"), there is a need to explore what field experts in the services industry experience on a daily basis. Therefore, the exploratory study will help answering questions such as: What are the different topics of positive customer feedback received in the services industries? What are the different forms, channels and time of administration of positive customer feedback in the services industries? What are the potential outcomes of positive customer feedback on service managers and employees? The multidisciplinary literature review, in conjunction with the exploratory study of the participants' insights, help uncover the components of the positive feedback model.

\section{Objective of the research study}

We seek to investigate the impact of positive customer feedback on front-line employee well-being, companies and society. To our best knowledge, no prior studies have explored these important issues. 
Therefore, two exploratory qualitative studies were conducted to gain deeper insights into this underresearched area: study 1 consisted of interviews with managers working in service sectors and study 2 consisted of focus groups with front-line service employees. The extensive literature review and the results of these two studies aim to contribute to the development of a "Positive Feedback Model" which can be further empirically tested in future studies. Managers' and employees' perceptions of positive customer feedback will also be compared.

\section{Study 1: managerial interviews}

\section{Data collection}

An exploratory study using semi-structured interviews with 22 managers was conducted to gain rich insights into managers' perceptions of positive customer feedback as well as its uses and impacts in today's service organizations. Respondents came from six UK companies (B2B and B2C) in the retail banking, retail, facilities management, food, and utilities sectors. Interviews lasted between 45 and 60 minutes and were audio-recoded and transcribed verbatim according to the guidelines of Stewart et al. (2007). An extensive interview guide including questions about managers' views and attitudes towards positive customer feedback was developed from a literature review. The guide was used to provide structure to the interviews, but participants were given the freedom to share issues and ideas not built into the interview guide.

Participants were selected from middle and top management (e.g., bank branch manager, key account manager, customer experience coach, network manager, section manager) to get deeper insights into the companies' customer feedback systems. The key topics explored during the interviews included: Attitudes towards customer feedback in general, current feedback management system in place, perception of positive customer feedback, perceived variations and impacts of positive customer feedback, the dissemination of positive customer feedback within the organization, the perceived accuracy and validity of the received positive customer feedback.

\section{Data analysis and findings}

An iterative hermeneutical process consisting of two stages was used to analyze the interview transcripts. First, the transcripts were closely read to grasp a meaning of the whole interview (Giorgi, 1989). During this phase key concepts were coded which subsequently helped identify the key themes. Second, we searched for similarities, differences and/or relationships between the key themes. The emerged key themes were grounded empirically in the data and well supported by evidence in the form of quotes described below. 
8 key themes were identified: Customer feedback perception and valence; positive feedback topic; positive feedback channel; positive feedback form; positive feedback time of administration; front-line employees' outcomes; company's outcomes and society's outcomes. Each theme will be discussed below.

Customer feedback perception and valence:

Customer feedback was described as an "opinion" or "information passed on to others". However, some managers disliked the usage of the term "feedback"; they preferred terms similar to "conversation"; "experience sharing"; "constructive communication". This is due to the negative connotation with the term "feedback". Subsequently, feedback valence was discussed. Participants agreed that most of the feedback received is negative and therefore, the first association with the word "feedback" is negative: "We sort of find, people always focus on the negative side, but the compliment side is not managed very well." (Female, Interview 20). Although the majority of the customer feedback has a negative valence, positive customer feedback is also received however, according to the managers, it is mismanaged. According to the managers, positive customer feedback differs in topic; channel; form and time of administration.

Positive feedback topic:

Although other positive feedback topics such as service excellence or servicescape were brought up during the interviews, the front-line employees' behavior, performance and appearance dominated the conversation. One manager mentioned: "Their (front-line employees) mannerisms and how they speak to the customer. Their actual personal look, (their) uniform” (Male, Interview 9).

Positive feedback channel:

The main channel for communicating positive customer feedback is the front-line employee who is, at the same time, the main recipient and subject of the positive feedback. Other feedback channels discussed included: customers approaching the manager to give feedback, social media, mail and emails, etc.: “They come into the branch, they'll phone Head Office, they'll do it by email to Head Office, we have seen it on Twitter now (Male, Interview 2)". Managers explained that positive customer feedback having the front-line employee as the main subject is always passed along to the employee for whom he or she gets recognized: "So if we get a good recommendation in from a client about somebody doing something well then we'll forward it on"(Female, Interview 12). Informal recognition takes the form of an informal comment or a "pat on the shoulder": "if we find something really good, or someone's done something to help this customer, and it's fantastic, we will go out and say, yes, a big, well done” (Female, Interview 5). While formal 
recognition ranges from monetary awards to the receipts of bonuses, certificates or plaques: "Recognition could be a form of certificates, highlighting that we've delivered great satisfaction for customers" and "people get awards for professionalism, integrity, expertise at their jobs, delivery to the client" (Male, Interview 17). Managers aim to communicate the positive feedback to the front-line employees because of the perceived beneficial impacts it has on them.

Positive feedback form:

Positive customer feedback form was described as being either verbal or written: "we've obviously got feedback that we get on a daily basis from our customers, verbally as they're banking and interacting with members of staff... we also had a box in the banking hall where they could put their compliments and thoughts down” (Female, Interview 12).

Positive feedback time of administration:

Time-wise, most of the positive customer feedback is received during the service encounter between the customer and the front-line employee or after the service encounter where the customer might communicate the compliment or the expression of gratitude through various feedback channels: "it might be still be 3 or 4 months down the line... so it is not always feedback right there” (Male, Interview 2).

Front-line employees' outcomes:

The participants discussed the impact of positive customer feedback on front-line employees. Managers talked about the "healthy competition" that might be boosted between front-line employees after receiving positive feedback. Other benefits described by the managers included motivation: "it gives them a little bit more of an extra drive ... just to have that good feedback" and "So it just feels good. (It is a) motivating factor. So they continue doing it" (Female, interview 3). Moreover, managers believed that positive customer feedback "boosts the confidence level up" (Male, interview 15).

Interestingly, managers were also critical about positive customer feedback as they believed it can be “double edged”. For example, a customer might give a positive feedback to ask for favors, or get a promotion. Therefore, positive customer feedback can be impersonal, not genuine, “we don't always trust where the positive feedback comes from" (Male, interview 6) it can be "given by a family member or a friend" (Female, interview 21), and might result in involuntarily favoring of complimenting customers over others. Managers also mentioned that some employees do not appreciate being praised in public or receiving certificates. The employee's personality plays a role in determining the impact of the feedback on him/her. Finally, some managers highlighted the demotivating impact that positive feedback can have on wellperforming employees when they realize that their less performing colleagues are being complimented: "one 
person's getting the praise and somebody else is doing a fantastic job" (Female, interview 3). They also suggested that for a continuously complimented employee, positive feedback can be dangerous as he/she might get too comfortable with the job and accordingly lose motivation.

\section{Company's outcomes:}

Managers also discussed the impact of positive customer feedback on the company. Some managers do not expect to receive positive customer feedback as the company is delivering the job it is charging for. For those managers, no feedback is positive feedback: "if you don't hear anything from the client it is sort of like a compliment anyway. Because things are running well" (Male, interview 1). For the managers, the real value of the customer feedback lies in that it provides guidance for improvement: "feedback is useless unless you're doing something with it" (Male, interview 6). Therefore, for most of the managers, constructive or actionable feedback is more important than positive feedback: "you don't want the nice stuff, you want the stuff you can improve on" (Male, interview 1). This finding comes in accordance with Wirtz et al.'s (2010) study stating that one of the main purposes of customer feedback management is improvement of overall service quality. Accordingly, for the managers, positive feedback is related to reputation, financial incentives and awards associated with it. The participants also explained that receiving positive feedback is a sign of good leadership: "It means that I'm leading by example, I'm showing my team what to do. Asking them to deliver my standards, which I think are quite high and to carry them on consistently rather than doing it for a day or a week, but continually do that day in day out, whether I was there or not, they wouldn't let their standards slip"(Male, interview 2). Therefore, the focus of the managers was more on the financial and managerial benefits as well as the reputation of the company/branch/section/team and the manager himself. This is illustrated by the following:

"If you want to progress and move into different roles, you need to be recognized for doing some great stuff. So being recognized by area and regional level means that if there's...not just for me but if there's anyone within my team that wants to progress, this is kind of a bit of ammunition to support that progression" (Female, interview 5).

Society's outcomes:

The participants also discussed the impact of positive customer feedback on society. In particular, this occurs during the corporate social responsibility activities that companies get involved in. During these activities, the occurrence of positive feedback increases and accordingly the employees' and managers' willingness to get involved in local initiatives increases too. Finally, participants mentioned the impact of positive feedback on society by explaining that it has a "spill-over" effect: "If somebody comes and says, oh what a fantastic branch this was this month because of this feedback, it breeds. It's a breeding culture isn't 
it?"(Female, interview 3). According to Palmer and Ponsonby (2002), social behavior is defined by sociocultural meaning systems and therefore marketing efforts and customer manifestations should be always considered as affecting and getting affected by particular social contexts. Consequently, the impact of positive customer feedback will surpass the individual level and accordingly will have an impact on the social system and the collectives at large since the employee's work related interactions affect the subsequent social interactions outside working hours.

\section{Summary}

The interviews provided insights into managers' perception of positive customer feedback and confirmed findings from previous studies in a new context i.e. the positive feedback context. First, positive customer feedback is underrated and less collated, and managers stressed that the current approaches and practices disregard the significant potential that positive feedback offers. Second, front-line employees are the main recipients and topics of positive customer feedback. Thus, the interviews confirmed the need to focus on exploring positive feedback addressed to front-line employees.

The interviews also helped identify the various positive customer feedback topics, forms, channels and timings of administration. These findings are crucial and novel as no previous research described the various categories of positive customer feedback in a service context. By having a holistic view of the customer feedback management system, managers were able to elaborate on the various components of positive customer feedback.

The interviews also confirmed our assumption that positive customer feedback transcends the individual front-line employee to encompass the company and the society as a whole, thus supporting the TSR approach adopted. Rosenbaum et al. (2011) suggest that consumers' individual actions, along with company's policies, will have social and communal impact. Consequently, we propose that the impact of positive customer feedback transcends the individual level (micro level) and affects the company (meso level) and social system at large (macro level). Finally, managers were critical about the impact of positive customer feedback regarding its actual effects on the well-being of front-line employees.

\section{Development of the Positive Feedback Model (PFM)}

Based on the multidisciplinary literature review and the findings of the managerial interviews, the following Positive Feedback Model (PFM) was developed (Figure 2). 
In particular, the literature review helped discover a set of context-free components, while the context-specific managerial interviews (positive customer feedback) helped to confirm and link these components which subsequently shaped the PFM.

Insert Figure 2 about here

Figure 2 consists of four columns. Column one represents the various topics of positive customer feedback. The second column represents the PsyCap capabilities. Between the first two columns, the hypothesized moderators are positioned (thin arrow), consisting of the form, channel and time of positive customer feedback administration. These hypothesized moderators were identified in the literature review and were subsequently confirmed by the managerial interviews. Accordingly, the various positive feedback topics (Appearance, Performance and Personality Traits) might have different impacts on the PsyCap if moderated by different form, channel or time of administration. For example, positive customer feedback complimenting the performance of a front-line employee addressed verbally face-to-face during a service encounter, might have a bigger impact on the optimism level of the front-line employee when compared to the same compliment addressed in writing to the manager after the service encounter. The hypothesized moderators can help in uncovering important managerial implications: whether particular positive feedback form, channel and time of administration have greater impact on the PsyCap. Moreover, the combination of the different positive feedback topics and the various hypothesized moderators might reveal important practical implications for companies. All of the above affects column three which is the front-line employee well-being.

The main focus in this paper is on the impact of positive feedback on the well-being of service entities (company and employees); the analysis of the managerial interviews confirmed that front-line employees are the main recipients of positive customer feedback and that they are also the main topic of positive feedback. Study 1 confirmed the importance of employees but lacked important insights that only employees could deliver. Hence, the need for study 2 was identified. Moreover, working within the TSR framework, the outcomes for the company and society are also included in the framework (column four) as managers discussed that positive customer feedback addressed to front-line employees will have positive outcomes for the company and society without specifying actual outcomes. The front-line employee outcomes are directly linked to front-line employee well-being (straight line connector in Figure 2). The other outcomes form an indirect relationship with front-line employee well-being (dotted line connector). 
Based on these findings, study 2 involving focus groups with front-line employees was conducted to get a deeper understanding of the specific impact of positive customer feedback on front-line employees.

\section{Study 2: focus groups with front-line employees}

Study 2 is necessary to gain knowledge from actual front-line employees working in various service industries who receive positive customer feedback on a daily basis. These employees might be able to potentially give support or discard some of the categories and connections discovered in the literature review and throughout the managerial interviews data analysis. Furthermore, they will be able to elaborate on the actual impacts that positive feedback has on their own well-being. Finally, stage 2 will help investigate whether managers' perceptions of positive customer feedback differ from the front-line employees perceptions.

\section{Data collection}

Focus group interviews have been predominantly used as an exploratory marketing research technique (Mullis and Lansing, 1986) when little is known about a particular phenomenon of interest (Stewart et al., 2007) - in this study: the impact of positive customer feedback on front-line employees. The literature review and the managerial interviews proposed that there is an impact on the front-line employee who is receiving positive feedback, however in order to uncover what specific types of impact, there is a need to explore the front-line employees' (actual subjects and recipients) perception of positive customer feedback.

An exploratory approach using focus groups was adopted since it gives access to the arguments and interpretations that participants (front-line employees) get involved with during a group interaction, this synergetic effect resulted in the production of data that might not have been uncovered in individual interviews (Stewart et al., 2007). Moreover, taking the nature of the participants into account, focus group interviews were deemed more appropriate to generate interesting and deeper discussion resulting in a snowballing effect where one comment of an individual triggers a chain of responses from the other participants. Finally, the nature of the topic (positive customer feedback) predicted a stimulation effect to take place during the focus groups interviews where participants' excitement over the topic increased and they were willing to share and express their ideas more freely (Hess, 1968).

A focus group pre-test was conducted with a sample of front-line employees $(n=6)$ working in different service industries. The purpose was to validate the interview guide developed after an extensive literature review and analysis of managerial interview data. The pre-test was also used to test the questions for clarity and appropriateness of the order of occurrence and to check the potential of the questions to 
generate a discussion between the participants of the focus group. Finally, we used the pre-test to investigate whether the interview guide questions help in meeting the particular purposes of the focus group. The pretest objectives were met.

Seven focus groups with front-line employees $(n=45)$ were conducted in seven locations across the UK. As recommended by Kruger (1994), the focus group consisted of six to eight participants both female and male. All participants worked as front-line service employees in various service companies representing different industries including the retail banking, retail, facilities management, food and utilities sectors, dealing with both businesses and customers. The key themes explored in the focus groups included: initial understanding of customer feedback, most memorable feedback, feedback type, topic, channel and time of administration, impact of positive feedback, role of the manager, and feedback management systems. The focus groups lasted between 70 and 90 minutes and were audio-recorded and transcribed verbatim following the guidelines of Stewart et al. (2007). The transcripts were coded and analyzed subsequently through content analysis.

\section{Data analysis and findings}

Content analysis is a systematic technique that aims to classify qualitative information based on pre-defined categories (Krippendorff, 1980). It aims to reach a detailed description of a particular phenomenon and the result of the analysis is categories explaining the phenomenon (Elo and Kyngas, 2008). The identified categories help building a conceptual system or framework (Elo and Kyngas, 2008). The process of analysis was inductive-deductive as this research was informed by previous knowledge (Proposed Model) while being context specific (positive customer feedback impact on front-line employees' well-being). Deductive content analysis was used as various categories were identified in the pre-developed model based on previous knowledge and accordingly the purpose was to test these categories while moving from the general to the specific (Burns and Grove, 2005). A categorization matrix was developed for this purpose where the aspects from the data that fits the categorization frame were selected. Moreover, emergent categories were identified through the detection of inductively derived themes where the aspects that did not fit the categorization frame were used to create new categories. For this purpose, an iterative process was used as we moved back and forth between the data and the model under development (Pratt et al., 2006). At first, open coding was used which helped develop the first-order codes. After each focus group, the inductively derived categories were reviewed to see if the data generated by the latest focus group fitted the previously set categories. If the revised data did not fit well into a category, this particular category was therefore revised or abandoned. Secondly, we moved from open coding to axial coding (Locke, 2001) and accordingly created theoretical categories which were more consolidated (combined data from all focus groups) and 
more abstract. Aggregate theoretical dimensions were identified after grouping categories that fit together into a coherent picture. Finally, the internal consistency was enhanced as one of the authors was the primary moderator and coder while regularly communicating with the other three authors (Kidd and Parchall, 2000). As analysis proceeded, content validity was secured as all the authors reviewed the coding scheme and the contents and definitions of coded categories both for the interviews and the focus group data (Atwood and Hinds, 1986).

Based on the analysis of the rich qualitative data generated through the conducted focus groups, the proposed model was adjusted (Figure 3).

Insert Figure 3 about here

The analysis of the data confirmed the previously established aggregate theoretical dimensions (themes): Positive feedback topic; form; channel; time; PsyCap; front-line employee's well-being; front-line employee's outcome; company's outcome and society's outcome. However, the data also revealed the following new theoretical categories:

Job attitude:

More theoretical categories were generated from the focus groups such as: "Job attitude" under Positive Feedback topic. One participant mentioned: “Probably staff attitude comes up quite a bit. I think that's a general feedback" (Male, Focus group 5). Employee smiling and employee friendliness were also identified as recurrent positive feedback topics coded under the theoretical category "job attitude".

Behavioral form of feedback:

"Behavioral" form of feedback is a subcategory within the aggregate theoretical dimension called "Form". It refers to any customer's action or behavior that the front-line employee categorizes as positive feedback (without actually being written or verbal). For example, the following statement was coded as behavioral feedback: “There's a couple that only deal with me and I couldn't even remember one of them, it was like 18 months ago, I dealt with him, and he would only deal with me, and it was just an ordinary billing query that he had, there was no reason to come through to me, but I was quite touched that he had even remembered my name, I didn't remember him at all”. (Female, focus group 3).

Positive feedback given "before" the service encounter: 
The focus group participants mentioned the occurrence of positive feedback before the service encounter when customers start the conversation with the employee by giving a compliment. This feedback timing is problematic as many employees question the sincerity of this feedback. Nevertheless, we decided to include this particular timing of feedback into our model as the purpose of this study is not to identify the motives behind giving positive feedback giving but rather the different types, forms, timings, etc.

\section{Theoretical categories under "Channel":}

The biggest contribution was made to the channel category where a multitude of channels was identified such as: "Other Customers"; "Other Employees"; "Media" and "Internal Systems". By "other customers" the participants meant getting compliments from customers who had heard positive feedback from someone else and then decided to pass it along to the concerned employee. "Other Employees" might pass along a positive feedback to a particular employee who was praised to them, by customers. "Media" covers all types of broadcast and print media that customers might use to give positive feedback. Finally, "internal systems" such as software or internal procedures (team meetings, departmental communication, etc.) might be used as channels to pass along positive feedback. These findings illustrate that companies should be aware of the various channels that customers use to give feedback about front-line employees.

\section{PsyCap:}

The usage of PsyCap was justified as various occurrences of positive feedback confirmed the impact on HERO. "You feel that you've done something, you've contributed to it to make that happen" (Male, focus group 1) was coded under Self efficacy. "It does sort of perk you up and make you feel better about yourself" (Male, focus group 2) was coded under Optimism.

Front-line employee's well-being:

Front-line employees mentioned experiencing Happiness; Inspiration; Positive Feelings and Positive Flow when they receive positive feedback. These dimensions were identified by Forgeard et al. (2011) as some of 7 subjective facets of well-being that have received the most attention in the various domains of well-being research conducted by psychologists and social scientists. Thus, our findings confirmed some of the approaches used to conceptualize well-being. Table 1 illustrates some examples of the coding process for the front-line employee well-being.

Insert Table 1 about here 
Front-line employee's outcomes:

Of particular interest are the theoretical categories generated under the "Front-Line Employee Outcome". As opposed to study 1, front-line employees were able to explain in details the outcomes of positive customer feedback: "Motivation"; "Job Satisfaction"; "Job Attitude" are included in figure 3. Table 2 illustrates some examples of the coding process for the front-line employee outcomes.

Insert Table 2 about here

Moreover, participants discussed how positive customer feedback can affect the well-being of the company and society, thus confirming the TSR approach adopted which states that any customer interaction with a service entity will have potential well-being outcomes both at the micro and macro levels (Anderson et al., 2013).

Company's outcomes:

Even though these aggregate theoretical dimensions were mentioned in the original model by the managers, more specific theoretical categories were generated by front-line employees such as: "Learning Capabilities" and "Service Experience". Some of these findings confirmed the benefits of customer feedback to the company, previously identified in the literature such as the study of Babbar and Koufteros (2008), identifying the improved organizational learning achieved through customer feedback.

Society's outcomes:

On a social level, positive feedback affects employees' interactions outside working hours, which leads to happier family and friends as one participant mentioned: "Had a really good day at work and obviously I go home and be happy there”...."You can't help but take your work home with you” (Male, focus group 2).

\section{Summary}

The focus groups provided a deeper understanding of front-line employees' perceptions of positive customer feedback. First, front-line employees confirmed that they are the major recipients and topic of the positive customer feedback received. The participants shared various examples of positive customer feedback topic, 
form, channel and timing while adding new sub-categories to the proposed model. For the front-line employees, positive customer feedback has a multitude of impacts on their psychological well-being thus confirming our proposition. Front-line employees were able to describe in details the various benefits positive feedback has on their well-being. Finally, front-line employees confirmed the appropriateness of the TSR approach adopted as they explained that positive customer feedback addressed to them, transcends their own individual well-being to affect the meso (company) and macro (society) levels.

\section{Comparison of manager and front-line employee perceptions}

One of the objectives of this study was to compare the managers' and employees' perceptions of positive customer feedback. Therefore, in this section, we begin by presenting the similarities and then turn to the differences in the managers' and employees' perceptions of positive customer feedback.

Both managers and front-line employees would like to receive more positive feedback. The results highlighted that positive customer feedback is underrated and not acted upon sufficiently in today's organizations. Moreover, both agreed that the current feedback systems used are designed with negativity in mind. Thus, making it easier for customers to complain rather than give compliments.

Both front-line employees and managers recognize the importance of receiving positive customer feedback but the internal communication is not always well established. Feedback is often held-up by the receiver, whether it is the employee, the manager or the top management. This finding supports Baker and Sinkula's (1999) study stating that customer feedback fails to become explicit knowledge and remains tacit because feedback received by front-line employees is rarely recorded or communicated to managers. This seems to be particularly the case for positive customer feedback. Moreover, for the employees, having a manager who communicates back positive customer feedback is a sign of supervisory support, which according to DeConinck (2010), makes them feel secure and aware that the organization takes care of their welfare. This is known as Perceived Supervisory Support (PSS) which constitutes employees' beliefs about the extent to which the supervisor appreciates their contribution and cares about their well-being (Kottke and Sharafinski, 1988). Variations in the capacity of managers to receive and pass on customer feedback were noted across the organizations depending on process complexity and how close to the point of service delivery managers sit. Previous research shows that employees' perception of their supervisors' support affects organizational objectives such as performance, organizational commitment, job satisfaction and turnover intentions (Eisenberger et al., 2004).

Both parties agreed that positive customer feedback transcends the individual receiving the feedback to encompass the organization and the society as a whole. As every front-line employee is a member of a company, the company is embedded within a social system. In addition, every front-line employee is a 
resource integrator and a member of a social system. Accordingly, there is a need to consider the "spillover" effect of customer feedback which starts by being addressed to one person and ends in having a radiating effect on the company and society at large.

While for the managers the real impact of positive customer feedback lies in the financial rewards, incentives and actionable and measurable plans, for front-line employees, positive feedback has various implications on their psychological well-being. Accordingly, positive feedback should not be ignored by companies and management as it provides a booster for employees' well-being which will be reflected in the employees' performance and overall welfare.

Finally, the understanding of what constitutes a "feedback channel" for a front-line employee might differ from the company's understanding. Therefore, more collaboration and dialogue between the two entities is needed. Moreover, there is a need for all organizations to work at breaking down barriers between (all levels of) staff and access to positive customer feedback.

\section{Limitations}

The main limitation of the study is that it is a small scale exploratory study and therefore the findings cannot automatically be projected to the population at large (Beck et al., 1986). Although the discussion within the interviews and focus groups was relatively unstructured, many groups discussed similar topics. The similarity of the topics supports the number of interviews and focus groups conducted since "saturation" of codes and categories was reached (Kruger, 1994). This, according to Rogers et al. (1998), supports the generalizability of the findings.

Another limitation of focus groups is conformity of opinions where members might feel the need to agree with the other group members and not express their true opinions (Garfinkel, 1967). This limitation was offset by the dynamics of attitudes and opinions created during the interaction of all the participants (Morgan, 1988) as it encouraged a degree of spontaneity in the communication of views (Butler, 1996).

A further limitation of the study is the adopted assumption that positive feedback is the only factor affecting front-line employee PsyCap and accordingly well-being. There is a wide literature on PsyCap in the area of organizational behavior, identifying various factors influencing the components of PsyCap (selfefficacy, hope, optimism, and resiliency). For example, self-efficacy, one of the state-like psychological resource capacities, is affected by experiencing and following the 'model' behavior of others and through responding to encouragement to engage in actions that lead to goal achievement (Maddux, 2002). It is only by measuring and controlling the impacts of the other factors on PsyCap that one can measure the actual impact of positive feedback on PsyCap. We recognize the existence of other factors affecting PsyCap, 
however, for this particular study, PsyCap was selected as a tool to study the outcomes of positive feedback while all the other factors were assumed to be stable.

\section{Directions for further research}

In terms of future research, empirical studies are required to measure the impact of positive customer feedback (compliments and gratitude) on the well-being of front-line employees. The findings of the suggested future empirical studies can have important managerial implications. For example, by uncovering which type of feedback has the highest impact on the employee PsyCap, companies might integrate particular positive feedback manifestations (depending on topic, form, channel, and time), into their training and motivation programs. In addition, by researching which particular types of compliments and expressions of gratitude have an impact on particular PsyCap component (HERO), the already established attitudinal, behavioral, and performance outcomes of each PsyCap component (and the high level of psychological well-being) can be linked to particular positive feedback manifestations. Companies could then investigate how to facilitate and encourage customers to engage in the particular forms of positive feedback that lead to improved employee well-being.

Researchers are also invited to test the relationship between the various categories of positive customer feedback, such as the various positive feedback channels identified, and newly discovered impacts such as job satisfaction, job attitude and motivation. In particular, social media and the growing occurrence of eWOM might be of interest for future research. Social media as positive customer feedback channel might hold many opportunities for the companies and researchers are invited to investigate research questions such as when/why/how does positive social media valence directly affect the size or growth of employee/ company / social outcomes? Finally, it is suggested that various feedback channels will have different impacts on the well-being of the recipients and it might be interesting to explore the various magnitudes and durations of these impacts.

Furthermore, working within the TSR framework, the impact of positive customer feedback on the well-being of consumer entities consisting of individuals, collectives, and ecosystems (Anderson et al., 2013) should be studied. While this paper focused on the impact of positive customer feedback on service entities, in particular front-line employees and companies, future studies can focus on the impact of positive feedback on the person addressing the feedback and accordingly the impact on the collectives and ecosystems that individuals belongs to. A positive feedback model for consumer entities could then be developed and subsequently be empirically tested. Finally, more empirical studies are needed from researchers in the services area as well as in macro-focused disciplines such as sociology to investigate the communal benefits of verbally expressed positive emotions. These studies will help explain the "spill-over" 
effect identified in this paper. Researchers are invited to study and measure the mechanisms by which the positive feedback impact transcends the well-being of the individual receiving the feedback by affecting the person's future interactions and the well-being of those he or she is interacting with. Further potential areas to explore include: the duration of the impact of positive feedback; the possible threshold level of this impact and the average number of future interactions this impact can affect.

Studies are also required on how to increase people's desire and willingness to express compliments and gratitude, for example, by promoting the design of social/advertising campaigns encouraging this particular type of pro-social behavior, researchers may contribute in creating a "reciprocity" effect. In order to be able to do so effectively, further understanding of the motives and attitudes towards positive feedback is needed. Questions such as why do people/customers express positive feedback, what are the various attitudes towards positive feedback, do various cultures and generations express positive feedback differently, and what might be their different motives behind giving praise, etc. could be addressed in future research. Here researchers can investigate "genuine" versus "fake" positive customer feedback (for example, from favor seeking customers or families and friends) and the ability of employees to spot the real intentions behind positive feedback giving. Accordingly, researchers can measure the variance of the impact on front-line employees' well-being, based on how genuine they believe the positive feedback to be.

In addition, the impact of the positive customer feedback might vary across cultures and generations. Future research might therefore test PFM in various cultural settings and across different age groups. Finally, studies around the implications of positive feedback in a variety of social contexts such as healthcare, education, transport, and social media are recommended. The usage of social network analysis and other techniques adopted from sociology may be valuable, as they enable the capturing of relationships within complex networks (Edvardsson et al., 2011).

\section{Conclusion}

This paper contributes to the literature on TSR and customer feedback management by studying the overlooked area of positive customer feedback impact on the well-being of service entities. Using a multidisciplinary approach, two exploratory qualitative studies were conducted. The extensive literature review and the results of these two studies contributed to the development of the "Positive Feedback Model" (PFM), which represents possible positive feedback categories, its various impacts and the outcomes on the parties involved. Finally, a comparison of the managerial and employees perceptions of positive customer feedback was made, followed by the presentation of novel managerial implications and directions for future research. We hope that fellow researchers will empirically test the proposed PFM in multiple contexts to enable further TSR advancement. 


\section{REFERENCES}

Algoe, S.B., Gable, S.L. and Maisel, N.C. (2010), "It's the little things: everyday gratitude as a booster shot for romantic relationships", Personal Relationships, Vol. 17 No. 2, pp. 217-233.

Anderson, L., Ostrom, A. and Bitner, M.J. (2010), "Services as social structures: consumer collectives and transformative services research", working paper, Arizona State University.

Anderson, L., Ostrom, A., Corus, C., Fisk, R.P., Gallan, A.S., Giraldo, M., Mende, M., Mulder, M., Rayburn, S.W., Rosenbaum, M.S., Shirahada, K. and Williams, J.D. (2013), "Transformative service research: an agenda for the future", Journal of Business Research, Vol. 66 No. 8, pp. 1203-1210.

Atwood, J. and Hinds, P. (1986), "Heuristic heresy: application of reliability and validity criteria to products of grounded theory", Western Journal of Nursing Research, Vol. 6 No. 2, pp. 135-147.

Avey, J.B., Luthans, F., Smith, R.M. and Palmer, N.F. (2010), "Impact of positive psychological capital on employee well-being over time", Journal of Occupational Health Psychology, Vol. 15 No. 1, pp. 17-28.

Babbar, S. and Koufteros, X. (2008), "The human element in airline service quality: contact personnel and the customer", International Journal of Operations \& Production Management, Vol. 28 No. 9, pp. 804830.

Baker, W.E. and Sinkula, J.M. (1999), "The synergistic effect of market orientation and learning orientation on organizational performance", Journal of the Academy of Marketing Science, Vol. 27 No. 4, pp. 411427.

Bateson, J. (1995), "Perceived control and the service encounter", in Czepiel, J., Solomon, M. and Surprenant, C. (Eds.), The Service Encounter: Managing Employee/Customer in Service Business, Lexington Books, Lexington, MA, pp. 67-82.

Beck, L., Trombetta, W. and Share, S. (1986), "Using focus group sessions before decisions are made", North Carolina Medical Joumal, Vol. 47 No. 2, pp. 73-74.

Bell, S.J. and Luddington, J.A. (2006), "Coping with customer complaints", Journal of Service Research, Vol. 8 No. 3, pp. 221-233.

Berry, L.L. and Parasuraman, A. (1997), "Listening to the customer - the concept of a service-quality information system", Sloan Management Review, Vol. 38 No. 3, pp. 65-76.

Best, A. and Andreasen, A.R. (1977), "Consumer response to unsatisfactory purchases: a survey of perceiving defects, voicing complaints, and obtaining redress", Law \& Society Review, Vol. 11 No. 4, pp. 701-742.

Bettencourt, L.A., Gwinner, K.P. and Meuter, M.L. (2001), "A comparison of attitude, personality, and knowledge predictors of service-oriented organizational citizenship behaviors", The Journal of Applied Psychology, Vol. 86 No. 1, pp. 29-41.

Bitner, M.J., Booms, B.H. and Mohr, L.A. (1994), "Critical service encounters: the employee's viewpoint", Journal of Marketing, Vol. 58 No. 4, pp. 95-106.

Blazevic, V., Hammedi, W., Garnefeld, I., Rust, R.T., Keiningham, T.L., Andreassen, T.W., Donthu, N. and Carl, W. (2013), "Beyond traditional word-of-mouth: an expanded model of customer-driven influence", Journal of Service Management, Vol. 24 No. 3, pp. 294-313.

Bowen, D., Schneider, B. and Kim, S. (2000), "Shaping service cultures through strategic human resource management", in Swartz, T. and Iacobucci, D. (Eds.), Handbook of Services Marketing and Management, Sage, Thousand Oaks, CA, pp. 439-454.

Butler, S. (1996), "Child protection or professional self-preservation by the baby nurses? Public health nurses and child protection in Ireland", Social Science \& Medicine, Vol. 43 No. 3, pp. 303-314.

Burns, N. and Grove, S.K. (2005), The Practice of Nursing Research: Conduct, Critique, and Utilization, 5th ed., Elsevier Saunders, St. Louis.

Day, R.L. and Landon, E.L. (1977), "Toward a theory of consumer complaint behavior", in Woodside, A.G., Sheth, J.N. and Bennett, P.D. (Eds.), Consumer and Industrial Buying Behavior, North Holland, New York, NY, pp. 425-437. 
DeConinck, J.B. (2010), "The effect of organizational justice, perceived organizational support, and perceived supervisor support on marketing employees' level of trust", Journal of Business Research, Vol. 63 No. 12, pp. 1349-1355.

Doorn, J., Lemon, K.N., Mittal, V., Nass, S., Pick, D., Pirner, P. and Verhoef, P.C. (2010), "Customer engagement behavior: theoretical foundations and research directions", Journal of Service Research, Vol. 13 No. 3, pp. 253-266.

Edmondson, D.R. and Boyer, S.L. (2013), "The moderating effect of the boundary spanning role on perceived supervisory support: a meta-analytic review", Journal of Business Research, Vol. 66 No. 11, pp. 2186-2192

Edvardsson, B., Tronvoll, B. and Gruber, T. (2011), "Expanding understanding of service exchange and value co-creation: a social construction approach", Journal of the Academy of Marketing Science, Vol. 39 No. 2, pp. 327-339.

Eisenberger, R., Lynch, P., Aselage, J. and Rohdieck, S. (2004), "Who takes the most revenge? individual differences in negative reciprocity norm endorsement", Personality and Social Psychology Bulletin, Vol. 30 No. 6, pp. 787-799.

Elo, S. and Kyngäs, H. (2008), "The qualitative content analysis process", Journal of Advanced Nursing, Vol. 62 No. 1, pp. 107-115.

Emmons, R.A. and McCullough, M.E. (2003), "Counting blessings versus burdens: an experimental investigation of gratitude and subjective well-being in daily life", Journal of Personality and Social Psychology, Vol. 84 No. 2, pp. 377-389.

Erickson, G.S. and Eckrich, D.W. (2001) "Consumer affairs responses to unsolicited consumer compliments", Journal of Marketing Management, Vol. 17 No. 3, pp. 321-340.

Fisk, R. (2009), "A customer liberation manifesto", Service Science, Vol. 1 No. 3, pp. 135-141.

Forgeard, M.J.C., Jayawickreme, E., Kern, M.L. and Seligman, M.E.P. (2011), "Doing the right thing: measuring wellbeing for public policy", International Journal of Wellbeing, Vol. 1 No. 1, pp. 79-106.

Fornell, C. and Wernerfelt, B. (1987), "Defensive marketing strategy by customer complaint management: a theoretical analysis", Journal of Marketing Research, Vol. 24 No. 4, pp. 337-346.

Fredrickson, B.L. (2004), "Gratitude, like other positive emotions, broadens and builds", in Emmons, R.A. and McCullough, M.E. (Eds.), Psychology of Gratitude, Oxford University Press, New York, NY, pp. 145-166.

Froh, J.J., Bono, G. and Emmons, R. (2010), "Being grateful is beyond good manners: gratitude and motivation to contribute to society among early adolescents", Motivation and Emotion, Vol. 34 No. 2 , pp. 144-157.

Garfinkel, H. (1967), Studies in Ethnomethodology, Prentice-Hall, Englewood Cliffs, NJ.

Giorgi, A.P. (1989), "Learning and memory from the perspective of phenomenological psychology", in Valle, R.S. and Halling, S. (Eds.), Existential-Phenomenological Perspectives in Psychology, Plenum, New York, NY, pp. 99-112.

Harter, J.K., Schmidt, F.L. and Hayes, T.L. (2002), "Business-unit level relationship between employee satisfaction, employee engagement, and business outcomes: a meta-analysis", Journal of Applied Psychology, Vol. 87 No. 2, pp. 268-279.

Hartline, M.D. and Ferrell, O.C. (1996), "The management of customer-contact service employees: an empirical investigation", Journal of Marketing, Vol. 60 No. 4, pp. 52-70.

Hartline, M.D., Maxham, J.G. III and Mckee, D.O. (2000), "Corridors of influence in the dissemination of customer-oriented strategy to customer contact service employees", Journal of Marketing, Vol. 64 No. 2, pp. 35-50.

Hatch, E. (1992), Discourse and Language Education, Cambridge University Press, Cambridge.

Herbert, R.K. and Straight, S.H. (1989), "Compliment-rejection versus compliment-avoidance: listenerbased versus speaker-based pragmatic", Language \& Communication, Vol. 9 No. 1, pp. 35-47.

Hess, J.M. (1968), "Group interviewing", in King, R.L. (Ed.), in 1968 ACR Fall Conference Proceedings, American Marketing Association, Chicago, pp. 193-196. 
Holmes, J. (1986), "Compliments and compliment responses in New Zealand", Anthropological Linguistics, Vol. 28 No. 4, pp. 485-508.

Howells, K. and Cumming, J. (2012), "Exploring the role of gratitude in the professional experience of preservice teachers", Teaching Education, Vol. 23 No. 1, pp. 71-88.

Kasper, H., Helsdingen, P.V. and Vries, W.D. (1999), Services Marketing Management: An International Perspective, John Wiley, New York, NY.

Kensinger, E.A. (2007), "Negative emotion enhances memory accuracy", Association of Psychological Science, Vol. 16 No. 4, pp. 213-218.

Kidd, P. and Parshall, M. (2000), "Getting the focus and the group: enhancing analytical rigor in focus group research", Qualitative Health Research, Vol. 10 No. 3, pp. 293-308.

Kottke, J.L. and Sharafinski, C.E. (1988), "Measuring perceived supervisory and organizational support", Educational and Psychological Measurement, Vol. 48 No. 4, pp. 1075-1079.

Kraft, F. and Martin, C. (2001), "Customer compliments as more than complementary feedback", Journal of Consumer Satisfaction, Dissatisfaction and Complaining Behavior, Vol. 14, pp. 1-13.

Krippendorff, K. (1980), Content Analysis: An Introduction to its Methodology, Sage, Newbury Park, CA.

Krueger, R.A. (1994), Focus Groups: A Practical Guide for Applied Research, 2nd ed., Sage, Thousand Oaks, CA.

Libai, B., Bolton, R., Bügel, M.S., de Ruyter, K., Götz, O., Risselada, H. and Stephen, A.T. (2010), "Customer-to-customer interactions: broadening the scope of word of mouth research", Journal of Service Research, Vol. 13 No. 3, pp. 267-282.

Litvin, S.W., Goldsmith, R.E. and Pan, B. (2008), "Electronic word-of-mouth in hospitality and tourism management", Tourism Management, Vol. 29 No. 3, pp. 458-468.

Locke, K. (2001), Grounded Theory in Management Research, Sage Publications, Thousand Oaks, London.

Lovelock, C. and Wirtz, J. (2010), Services Marketing: People, Technology, Strategy, Pearson/Prentice Hall, Upper Saddle River, New Jersey, NJ.

Lusch, R.F. and Vargo, S.L. (2006), "Service-dominant logic as a foundation for a general theory", in Lusch, R.F. and Vargo, S.L. (Eds.), The Service-Dominant Logic of Marketing, Sharpe Inc., New York, ME, pp. 406-420.

Lusch, R.F., Vargo, S.L. and O'Brien, M. (2007), "Competing through service: insights from servicedominant logic", Journal of Retailing, Vol. 83 No. 1, pp. 5-18.

Luthans, F. (2002), "The need for and meaning of positive organizational behavior", Journal of Organizational Behavior, Vol. 23 No. 6, pp. 695-706.

Luthans, F. and Avolio, B.J. (2009), "The "point" of positive organizational behavior", Journal of Organizational Behavior, Vol. 30 No. 2, pp. 291-307.

Luthans, F. and Youssef, C.M. (2004), "Human, social, and now positive psychological capital management", Organizational Dynamics, Vol. 33 No. 2, pp. 143-160.

Luthans, F. and Youssef, C.M. (2007), "Emerging positive organizational behavior", Journal of Management, Vol. 33 No. 3, pp. 321-349.

Maddux, J.E. (2002), "Self-efficacy: the power of believing you can", in Snyder, C.R. and Lopez, S.J. (Eds.), Handbook of Positive Psychology, Oxford University Press, New York, pp. 277-287.

Manes, J. and Wolfson, N. (1981), "The compliment formula", in Coulmas, F. (Ed.), Conversational Routine: Explorations in Standardized Communication Situations and Prepatterned Speech, Mouton, The Hague, pp. 115-132.

Maxham, J.G. and Netemeyer, R.G. (2002), "A longitudinal study of complaining customers' evaluation of multiple service failures and recovery efforts", Journal of Marketing, Vol. 66 No. 4, pp. 57-71.

Money, K., Hillenbrand, C. and Camara, N.D. (2009), "Putting positive psychology to work in organisations", Journal of General Management, Vol. 34 No. 3, pp. 21-36.

Morgan, D.L. (1988), Focus Groups as Qualitative Research, Sage Publications, Thousand Oaks, CA.

Mullis, R. and Lansing, D. (1986), "Using focus groups to plan worksite nutrition programs", Journal of Nutritional Education, Vol. 18 No. 1, pp. 532-534.

Myers, D.G. and Diener, E. (1995), "Who is happy?", Psychological Science, Vol. 6 No. 1, pp. 10-17. 
Ostrom, A.L., Bitner, M.J., Brown, S.W., Burkhard, K.A., Goul, M., Smith-Daniels, V., Demirkan, H. and Rabinovich, E. (2010), "Moving forward and making a difference: research priorities for the science of service", Journal of Service Research, Vol. 13 No. 1, pp. 4-36.

Palmer, A. and Ponsonby, S. (2002), "The social construction of new marketing paradigms: the influence of personal perspective", Journal of Marketing Management, Vol. 18 No. 1, pp. 173-192.

Pearson, M.M. (1976), "A note on business replies to consumer letters of praise and complaint", Journal of Business Research, Vol. 4 No. 1, pp. 61-68.

Pratt, M.G., Rockmann, K.W. and Kaufmann, J.B. (2006), "Constructing professional identity: the role of work and identity learning cycles in the customization of identity among medical residents", Academy of Management Journal, Vol. 49 No. 2, pp. 235-262.

Quick, J.C. and Quick, J.D. (2004), "Healthy, happy, productive work: a leadership challenge", Organizational Dynamics, Vol. 33 No. 4, pp. 329-337.

Rayport, J.F. and Jaworski, B.J. (2004), "Best face forward", Harvard Business Review, Vol. 82 No. 12, pp. 47-58.

Robertson, I. and Cooper, C. (2011), Well-Being: Productivity and Happiness at Work, Palgrave MacMillan, Basingstoke.

Robertson, P.J. (1995), "Involvement in boundary-spanning activity: mitigating the relationship between work setting and behavior", Journal of Public Administration Research and Theory, Vol. 5 No. 1, pp. 7398.

Rogers, W.A., Meyer, B., Walker, N. and Fisk, A.D. (1998), "Functional limitations to daily living tasks in the aged: a focus group analysis", Human Factors, Vol. 40 No. 1, pp. 111-125.

Rosenbaum, M.S., Corus, C., Ostrom, A.L., Anderson, L., Fisk, R.P., Gallan, A.S., Giraldo, M., Mende, M., Mulder, M., Rayburn, S.W., Shirahada, K. and Williams, J.D. (2011), "Conceptualisation and aspirations of transformative service research", Journal of Research for Consumers, Vol. 19, pp. 1-6.

Sampson, S.E. (1996), "Ramifications of monitoring service quality through passively solicited customer feedback", Decision Sciences, Vol. 27 No. 4, pp. 601-622.

Schneider, B. and Bowen, D.E. (1999), "Understanding consumer delight and outrage", Sloan Management Review, Vol. 41 No. 1, pp. 35-45.

Smith, A.K., Bolton, R.N. and Wagner, J. (1999), "A model of customer satisfaction with service encounters involving failure and recovery", Journal of Marketing Research, Vol. 36 No. 3, pp. 356-372.

Spector, P.E. (1997), Job Satisfaction: Application, Assessment, Causes, and Consequences, Sage, Thousand Oaks, CA.

Stewart, D., Shamdasani, P. and Rook, D. (2007), Focus Groups Theory and Practice, Sage, London, UK.

Van der Heijden, G.A.H., Schepers, J.J.L., Nijssen, E.J. and Ordanini, A. (2013), "Don't just fix it, make it better! using frontline service employees to improve recovery performance", Journal of the Academy of Marketing Science, Vol. 41 No. 5, pp. 515-530.

Vargo, S.L. and Lusch, R.F. (2008), "Service-dominant logic: continuing the evolution", Journal of the Academy of Marketing Science, Vol. 36 No. 1, pp. 1-10.

Verhoef, P.C., Reinartz, W.J. and Krafft, M. (2010), "Customer engagement as a new perspective in customer management", Journal of Service Research, Vol. 13 No. 3, pp. 247-252.

White, P. (1999), "Gratitude, citizenship and education", Studies in Philosophy and Education, Vol. 18 No. 1-2, pp. 43-52.

Wirtz, J., Tambyah, S.K. and Mattila, A.S. (2010), "Organizational learning from customer feedback received by service employees - a social capital perspective", Journal of Service Management, Vol. 21 No. 3, pp. 363-387.

Wood, A.M., Maltby, J., Stewart, N., Linley, P.A. and Joseph, S. (2008), "A social-cognitive model of trait and state levels of gratitude", Emotion, Vol. 8 No. 2, pp. 281-290.

Young, M.E. and Hutchinson, T.S. (2012), "The rediscovery of gratitude: implications for counselling practice", Journal of Humanistic Counseling, Vol. 51 No. 1, pp. 99-113. 
Figure 1. Dimensions of PsyCap

\begin{tabular}{|ll|}
\hline $\begin{array}{l}\text { Positive } \\
\text { Psychological } \\
\text { Capital }\end{array}$ & $\begin{array}{l}\text { Hope: "Having the willpower and pathways to attain one's } \\
\text { goals." }\end{array}$ \\
\cline { 2 - 2 } & $\begin{array}{l}\text { Efficacy: "Believing in one's ability to mobilize cognitive resources } \\
\text { to attain specific outcomes." }\end{array}$ \\
\hline $\begin{array}{l}\text { Resiliency: "Having the capacity to bounce back from adversity, } \\
\text { failure or even seeming overwhelming positive changes." }\end{array}$ \\
$\begin{array}{l}\text { Optimism: "Having an exploratory style that attributes positive } \\
\text { events to internal, permanent and pervasive causes." }\end{array}$ \\
\hline
\end{tabular}

Source: Adapted from Luthans and Youssef (2004, p. 152) 
Figure 2. Proposed Positive Feedback Model (PFM)

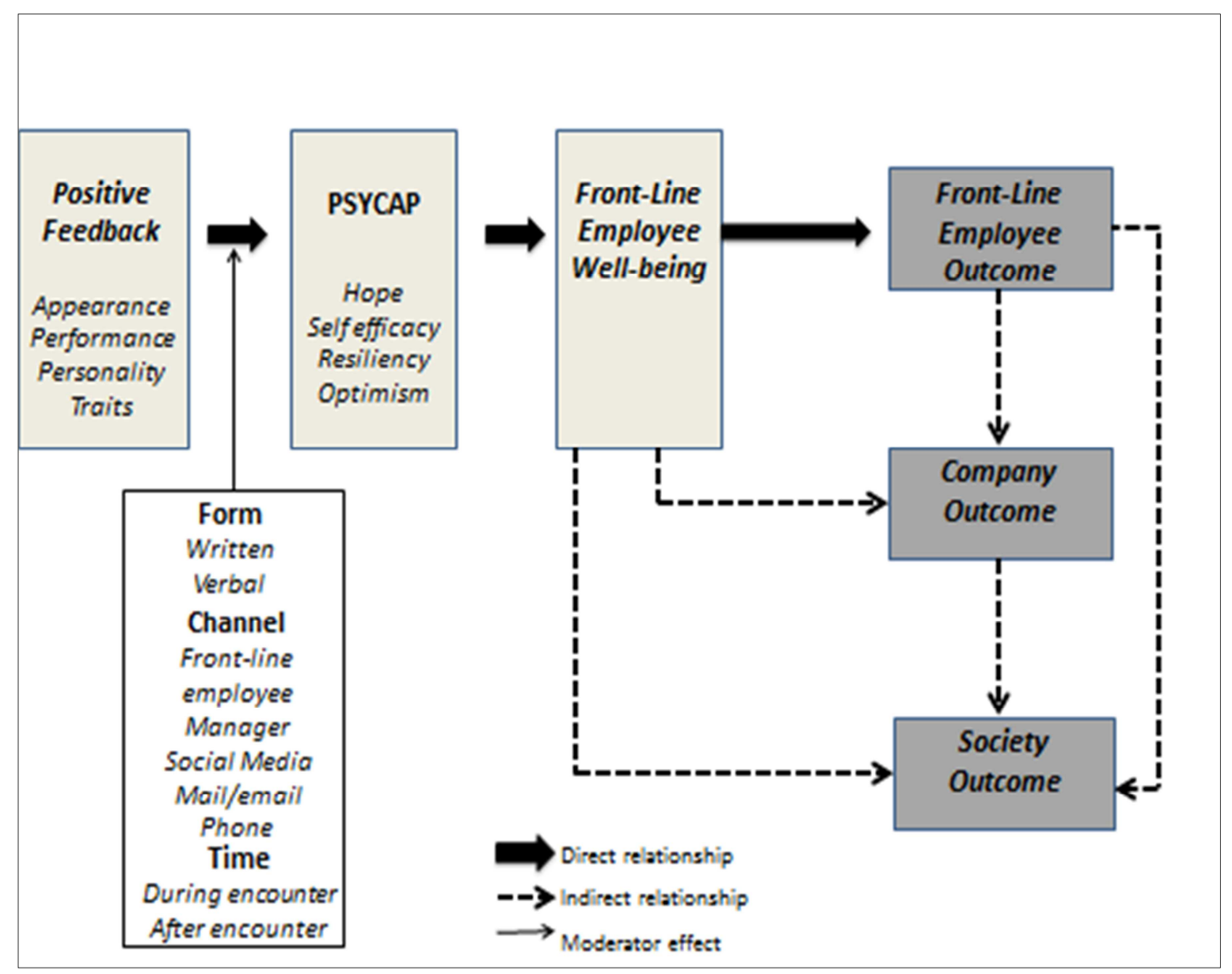


Figure 3. Adjusted Positive Feedback Model (PFM)

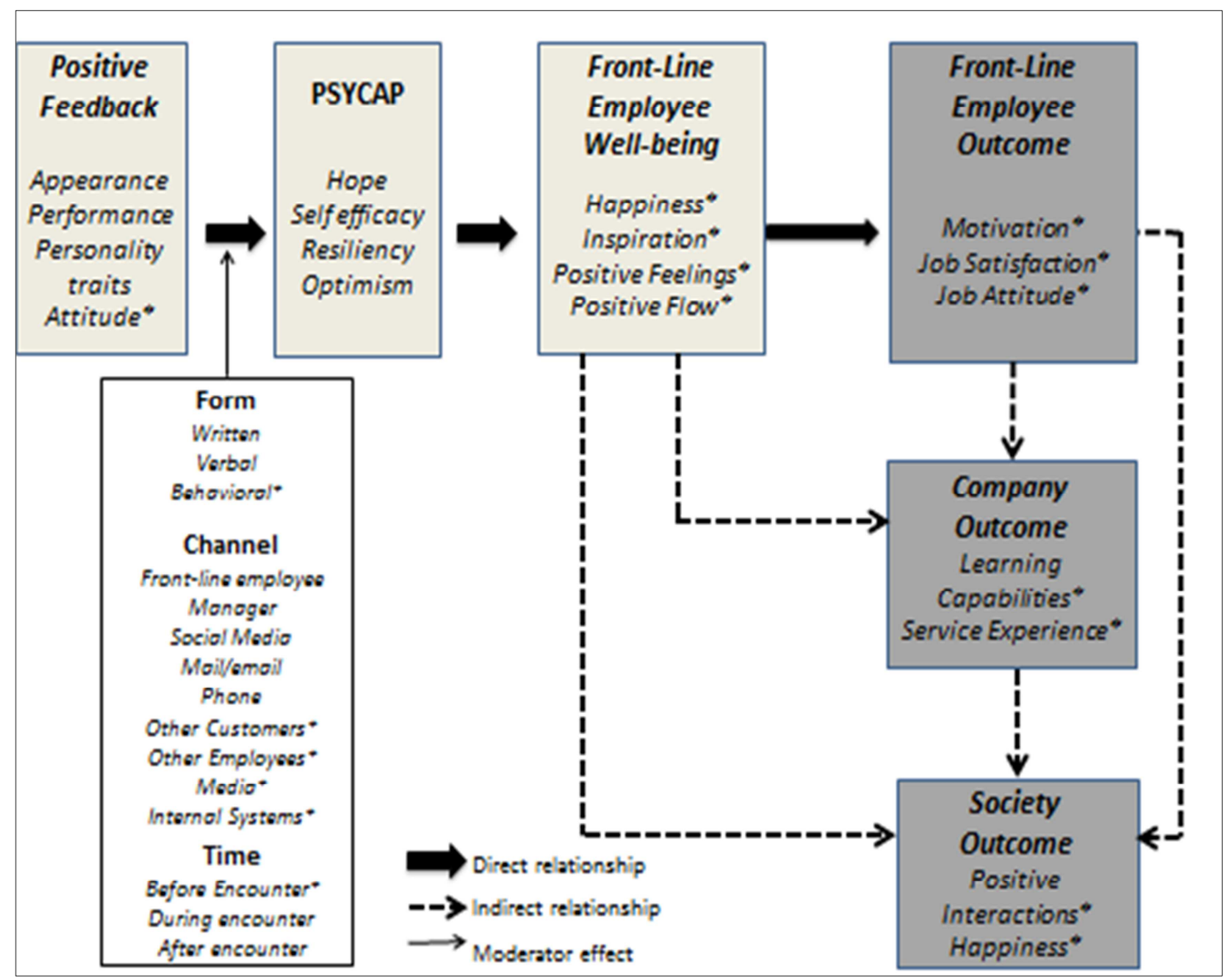

*Categories generated from the focus groups analysis 
Table 1. Overview of coding structure (front-line employee's well-being):

\begin{tabular}{|l|c|c|}
\hline \multicolumn{1}{|c|}{ First order codes } & Theoretical categories & $\begin{array}{c}\text { Aggregate } \\
\text { theoretical } \\
\text { dimensions }\end{array}$ \\
\hline $\begin{array}{l}\text { "So that was quite powerful, and you do find yourself } \\
\text { walking on air for the next half hour when that } \\
\text { happens" (Female, focus group 5). }\end{array}$ & Happiness & $\begin{array}{c}\text { Front-Line } \\
\text { Employee Well- } \\
\text { being }\end{array}$ \\
\hline $\begin{array}{l}\text { "So I think when you get that type of feedback come } \\
\text { through you think I know I'm doing a good job, and it } \\
\text { does inspire you to continue to have that type of } \\
\text { impact with people, and it does inspire you to go the } \\
\text { extra mile as well" (Female, focus group 3). }\end{array}$ & Inspiration & $\begin{array}{c}\text { Front-Line } \\
\text { Employee Well- } \\
\text { being }\end{array}$ \\
\hline $\begin{array}{l}\text { "But you get a good response all day long and it just } \\
\text { seems to just flow and flow and flow. So it's your } \\
\text { mind isn't it? It's in the brain and when you get that } \\
\text { positive flow, it just keeps going" (Male, focus group } \\
\text { 2). }\end{array}$ & Positive Flow & $\begin{array}{c}\text { Employee Well- } \\
\text { being }\end{array}$ \\
\hline $\begin{array}{l}\text { "It makes you know that you are special... It makes } \\
\text { you proud of yourself" (Female, focus group 6). }\end{array}$ & Positive Feelings & $\begin{array}{c}\text { Front-Line } \\
\text { Employee Well- } \\
\text { being }\end{array}$ \\
\hline
\end{tabular}


Table 2. Overview of coding structure (front-line employee's outcomes):

\begin{tabular}{|l|c|c|}
\hline \multicolumn{1}{|c|}{ First order codes } & $\begin{array}{c}\text { Aggregate } \\
\text { theoretical } \\
\text { dimensions }\end{array}$ \\
\hline $\begin{array}{l}\text { "It kind of gives me more incentive at the same time, } \\
\text { it's like okay, I'm helping these guys, I've got a } \\
\text { bigger responsibility than just my own little till to } \\
\text { focus on my customer in front of me" (Male, focus } \\
\text { group 4). }\end{array}$ & Motivation & $\begin{array}{c}\text { Front-Line } \\
\text { Employee } \\
\text { Outcome }\end{array}$ \\
\hline $\begin{array}{l}\text { "I'm now trying to help everyone come together, and } \\
\text { personally enjoy doing stuff like that, so I don't mind } \\
\text { helping other cashiers. And it makes me acknowledge } \\
\text { that I'm getting noticed as well. At the same time it's } \\
\text { a good acknowledgement to have, that the manager } \\
\text { themselves would trust me to have a huddle to then } \\
\text { explain what I'm doing well and how we can } \\
\text { implement it throughout everyone. I think that's one } \\
\text { of the most rewarding feedbacks ever I think" (Male, } \\
\text { focus group 1). }\end{array}$ & Job Satisfaction & \\
\hline $\begin{array}{l}\text { "It gives you confidence in what you are doing. It's } \\
\text { when you know you are doing the right things and } \\
\text { you are being commended for it. Because when you } \\
\text { are doing it and you don't get much feedback, you } \\
\text { don't know whether you are doing the right thing or } \\
\text { wrong thing, so your confidence isn't there" (Female, } \\
\text { focus group 4). }\end{array}$ & & $\begin{array}{l}\text { Fmployee } \\
\text { Outcome }\end{array}$ \\
\hline
\end{tabular}

